\title{
PENGALAMAN BERSUA TUHAN: Perspektif William James dan al-Ghazali
}

\author{
Komarudin \\ IAIN Walisongo Semarang \\ e-mail: komarudin@yahoo.com
}

\begin{abstract}
Experience of meeting God constitutes an interresting phenomenon and become the focus of interrest of many disciplines. Psychology and tasawuf are two disciplines which focusedly study this phenomenon applying different approaches. Ghazali is the representative of the dicsipline of tasawwuf and William James is the representative of the dicsipline of psychology. The both experts applied the different approaches in studying the religious experiences. Epistemological base on which William James used, has the scientific accountability but less accurate in the source of knowledge. In other side, Ghazali has a deep source of knowledge but less of rationality. An effort to compromise the both approach in order to study about the experience of meeting God will result in a comprehensive, deep, and objective depiction.

Pengalaman bersua Tuhan merupakan fenomena yang menarik dan menjadi titik perhatian banyak disiplin ilmu. Psikologi dan tasawuf merupakan dua disiplin ilmu yang memfokuskan kajiannya pada fenomena ini dengan menerapkan pendekatan yang berbeda. Ghazali adalah representasi dari disiplin ilmu tasawuf dan William James adalah representasi disiplin ilmu psikologi. Kedua ahli tersebut menggunakan pendekatan yang berbeda dalam mengkaji pengalaman keagamaan. Basis epistimologi yang digunakan oleh James memiliki akuntabilitas ilmiah namun kurang akurat dalam sumber pengetahuannya. Di sisi lain Ghazali memiliki sumber pengetahuan yang dalam namun kurang dari sisi rasionalitas. Upaya untuk mengkompromikan kedua pendekatan dalam rangka untuk mengkaji pengalaman bersua Tuhan akan menghasilkan penggambaran yang dalam dan obyektif.
\end{abstract}

Keywords: pengalaman religius, ma'rifat, psikologi, tasawuf 


\section{A. Pendahuluan}

Pengalaman manusia bersua dengan Realitas Adikodrati, yakni Tuhan, sepanjang sejarah manusia menarik perhatian para ahli atau intelektual. Dalam tradisi pemikiran Islam, persoalan tersebut telah melahirkan kontroversi dan perdebatan yang amat panjang. Ambil contoh, misalnya pengalaman spiritual yang dialami Mansur al-Hallaj, Abu Yazid al-Bustami, Ibn alArabi, Suhrawardi al-Maqtul, dan yang lainnya, ternyata telah melahirkan gejolak penolakan luar biasa dari para pendukung ortodoksi Islam. Imam alGhazali pun, yang merupakan representasi kaum ortodoksi Sunni, menyayangkan proses pengungkapan pengalaman seperti itu di hadapan orangorang awam, meskipun sebenarnya al-Ghazali sendiri mengakui kebenaran pengalaman religius seperti itu.

Meskipun penolakan terhadap kebenaran pengalaman religius seperti di atas masih saja bergulir hingga sekarang, namun di sisi lain ternyata masih banyak tokoh yang respek, dan mereka pun mencoba melakukan kajian terhadapnya. Mulla Sadra yang datang setelah Suhrawardi telah berhasil menyempurnakan madhhab al-Ishraqiy yang dibangun oleh salah satu tokoh sufi-filosofis Syaikh Syihab al-Din Suhrawardi. Begitu pula, sebelum datangnya Mulla Sadra (w. 1041 H), dalam tradisi Sunni juga terdapat beberapa tokoh yang berhasil mensintesakan antara teologi dan filsafat, sehingga banyak dari pemikiran mereka memiliki warna yang bercorak teosofis-transendental, seperti Qadhi Adud al-Iji, Sa'ad al-Din al-Taftazani dan Syarif al-Durjani. Tradisi seperti ini, dalam mazhab Sunni, ternyata masih tetap berlangsung hingga kedatangan Syah Waliyullah dan bahkan masih diajarkan di berbagai sekolah Sunni. ${ }^{1}$

Syekh Ahmad Sirhindi yang hidup pada abad ke-16 dan 17 juga tertarik untuk melanjutkan tradisi sufistik-filosofis dan mencoba mempertemukan antara dimensi-dimensi pengalaman spiritual yang telah dibangun oleh para sufi besar seperti Ibn al-Arabi (w. 638 H) dengan syariat Islam. Kemudian ia pun melontarkan gagasan wahdat al-shuhūd sebagaimana yang telah dilontarkan oleh penyair sufistik terkenal Ibn Faridh dan Jalaluddin Rumi ${ }^{2}$

\footnotetext{
${ }^{1}$ Lihat Jalaluddin Rahmad dalam komentarnya dalam buku Mulla Sadra, Kearifan Puncak, terj. Dr.Ir. Dimitri Mahayana dan Ir. Dedi Djunardi, (Yogyakarta: Pustaka Pelajar, 2001), h. xi.

2 Lihat Dr. Muhammad Abd. Haq Ansari, Merajut Tradisi Syari'ah dengan Sufisme, terj. Achmad Nashir Budiman, (Jakarta: Grafindo Persada, 1997), h. 7-9.
} 
Begitu pula Muhammad Iqbal, dalam bukunya The Reconstruction of Religious Thouhgt in Islam, mencoba membeberkan keberadaan pengalaman keagamaan (religious experience) serta alat uji kebenarannya. ${ }^{3}$

Ketertarikan studi terhadap pengalaman keagamaan (religious experience) juga terjadi di dunia Barat. Bahkan beberapa orientalis Barat mulai tertarik untuk meneliti pengalaman religius tokoh-tokoh sufi Muslim besar, seperti al-Hallaj dan Ibn al-Arabi. ${ }^{4}$ Sebagai sekedar contoh, misalnya William C. Chittick yang telah berhasil melakukan kajian mendalam terhadap karya Ibn al-Arabi Futūhat al-Makkiyyah yang kemudian ia susun ke dalam triloginya The Sufi Path of Knowledge. Begitu pula Annemarie Schimmel mencoba menyoroti dimensi mistik dalam Islam. Juga, Toshihiko Izutsu mencoba melakukan kajian tentang Relasi Tuhan dan Manusia dengan menggunakan pendekatan semantik terhadap al-Qur'an. Begitu pula, beberapa intelektual Indonesia sendiri juga melakukan kajian terhadap eksistensi pengalaman keagamaan para sufi besar, seperti yang telah dilakukan oleh Dr. Kautsar Azhari Noer. ${ }^{5}$

Ketertarikan terhadap pengalaman keagamaan (religious experience) yang bersifat subjektif dan unik seperti itu, juga mendorong sebagian pendukung disiplin psikologi untuk mengajinya dengan mengikuti kaidahkaidah ilmiah. Salah satu tokoh di bidang psikologi, sekaligus merupakan salah satu pendiri aliran filsafat pragmatisme, yang tertarik mengkaji secara rinci persoalan pengalaman keagamaan (religious experience), adalah William James. Menurutnya, pengalaman-pengalaman keagamaan seperti itu tetap saja merupakan fenomena yang tidak mungkin diabaikan begitu saja. William James sendiri berusaha menolak tesis-tesis dan pandangan-pandangan penganut Materialisme Medis yang menolak kebenaran adanya pengalaman religius yang bersifat unik dan subjektif tersebut. James menegaskan bahwa

\footnotetext{
3 Lihat Muhammad Iqbal, The Reconstruction of Religious in Islam (Pembangunan Kembali Alam Pikiran Islam), terj. Osman Raliby, (Jakarta: Bulan Bintang, 1883), h. 62-63.

${ }^{4}$ Sebagai sekedar contoh, misalkan lihat William C. Chittick yang telah berhasil melakukan kajian mendalam terhadap karya Ibn al-'Arabi, Futūhat al-Makkiyyah yang kemudian ia susun ke dalam triloginya the Sufi Path of Knowledge. Begitu pula Annemarie Schimmel mencoba menyoroti dimensi mistik dalam Islam. Juga, Toshihiko Izutsu mencoba melakukan kajian tentang Relasi Tuhan dan Manusia dengan menggunakan pendekatan semantik terhadap al-Qur'an.

${ }^{5}$ Lihat disertasinya yang telah diterbitkan dengan judul Ibn a-l'Arabi Wahdat al-Wujud dalam Perdebatan yang diterbitkan oleh Paramadina.
} 
pengalaman-pengalaman religius tersebut berakar pada kondisi kesadaran mistis, yang bersifat unik dan personal, sehingga perlu pendekatan filsafat untuk menjadikannya sebagai azas-azas yang lebih umum. ${ }^{6}$ Oleh karena itu, James berusaha memasukkan masalah pengalaman keagamaan seperti ini masuk dalam bahasan psikologi. Langkah ini patut mendapat apresiasi, karena mencoba mengungkap aspek keilmiahan dari sebuah pengalaman yang bersifat unik dan subjektif, yang oleh para eksponen psikologi lainnya dianggap tidak lazim dan tidak ilmiah. Upaya seperti ini juga telah dijadikan sebagai landasan atau dasar bagi pengembangan psikologi agama.

Dalam sisi yang lain, persoalan pengalaman keagamaan (religious experience) seperti itu telah mendapatkan takdir pembahasannya yang lebih intens dalam tradisi tasawuf atau gnostik Islam. Di antara tokoh sufi yang telah melakukan pembahasan mengenai persoalan pengalaman keagamaan seperti di atas adalah al-Ghazali. Meski dirinya termasuk dalam kelompok sufi Sunni, tetapi pembahasannya mengenai pengalaman puncak para sufi terbilang cukup luas. Melalui konsep ma'rifat billāh dan konsep ilmu mukashafah (fanā)-nya ia hendak menjelaskan hakikat pengalaman spiritual sufistik tersebut yang telah menimbulkan kesalahpahaman dan kekeliruan bagi para pendukung dan penolaknya. Menurutnya, seorang sufi atau arif sering mengalami pengalaman kesatupaduan antara yang tunggal dengan yang jamak. Tetapi kesatupaduan yang dimaksudkan tersebut, menurut al-Ghazali bukan kesatupaduan yang bercorak eksistensial, tetapi berdasarkan penyaksian atau kesadaran yang berlangsung pada diri seorang sufi sewaktu dalam keadaan fana. Ia juga menyatakan bahwa seorang arif tidak melihat yang selain Allah serta dia tidak tahu yang selain-Nya. Yang dia tahu dalam wujud ini hanyalah Dia dan kreasi-kreasi-Nya. Dalam keadaan seperti itu dia tidak melihat sesuatu sebagai kreasi semata kecuali bahwa dia justeru melihat Kreatornya dan dia mengabaikan kreasi-kreasi tersebut dengan predikat-predikatnya seperti langit, bumi, hewan, atau pohon tetapi sebaliknya dia melihat kesemuanya itu sebagai kreasi Dzat Yang maha Esa lagi Maha Benar. Dalam keadaan seperti ini, seorang arif adalah orang yang benar-benar mencintai Allah dan mengesakan-Nya. Karena baginya, tidak ada yang ia lihat kecuali Allah, tidak ada yang dicintai kecuali Allah. Bahkan dia tidak

${ }^{6}$ Lihat Pengantar dari Hanna Djumhana Bastaman dalam William James, ibid., h. 24. 
memandang dirinya dari segi dirinya sendiri, tapi dari segi predikatnya sebagai hamba Allah. Atas dasar pengalaman seorang arif seperti ini, al-Ghazali kemudian berusaha mengklasifikasikan teori tauhid menjadi empat kategori, yaitu tauhid orang-orang munafik, tauhid orang awam, tauhid orang-orang alMuqarrabin, dan kategori tauhid penyaksian orang-orang al-șiddīqīn. ${ }^{7}$

Apa yang dilakukan al-Ghazali pada dasarnya hendak mengklarifikasi kebenaran pengalaman keagamaan yang diungkapkan para sufi atau arif billah seperti itu. Hal ini, tampak ada kemiripan dengan apa yang dilakukan oleh William James. Jika al-Ghazali hendak berusaha memperjelas kesalahpahaman dan kekeliruan yang terjadi di antara para sufi, yakni antara para pendukung dan penolaknya, William James hendak memperjelas keabsahan kajian atas pengalaman-pengalaman keagamaan tersebut sebagai bagian dari kajian disiplin psikologi. Sebagaimana telah disebutkan di atas, sebagian besar kalangan pendukung disiplin psikologi menolak memasukkan bahasan pengalaman keagamaan sepeti ini sebagai bagian dari kajian psikologi, karena mereka anggap tidak memenuhi kriteria-kriteria ilmiah.

Atas dasar inilah, peneliti tertarik untuk mengkaji lebih jauh pemahaman kedua tokoh tersebut terhadap persoalan pengalaman keagamaan (religious experience) yang sering dialami oleh orang-orang tertentu, serta berusaha membandingkan konstruk epistemology di antara keduanya. Karena itu, peneliti mencoba mengajukan judul penelitian sebagai berikut, "Pengalaman Bersua Tuhan: Studi Perbandingan antara Pandangan William James dan al-Ghazali."

\section{B. Pengalaman Bersua Tuhan dalam Pandangan William James dan al-Ghazali}

Relasi individu dengan hal yang diyakini sebagai yang Ilahi atau Tuhan telah melahirkan pengalaman keagamaan yang unik dan subjektif, yakni berupa pengalaman bersua dengan Tuhan. Ini merupakan bentuk pengalaman puncak (peak exsperience) seseorang, yang buah-buahnya tampak jelas dalam diri individu, terutama pada diri individu-individu yang kudus. Dalam diri individu tersebut terdapat suatu keyakinan akan adanya realitas

\footnotetext{
7 Lihat Abu al-Wafa' al-Ghanimi al-Taftazani, Sufi dari Zaman ke Zaman, terj. Ahmad Rofi' Utsmani, (Bandung: Pustaka,1985), h. 178.
} 
tatanan gaib yang dijadikan sebagai pusat perhatian serta inspirasi untuk melakukan penyesuaian secara sempurna. Menurut James, keyakinan terhadap realitas tatanan yang gaib seperti itu serta upaya penyesuaian diri dengan tatanan yang gaib seperti itu merupakan sikap keagamaan dalam jiwa seseorang. ${ }^{8}$

Menurut James keyakinan kepada tatanan yang gaib seperti itu tidak lain berupa sebuah keyakinan akan adanya sebuah objek yang tidak bisa dilihat secara empiris atau melalui panca indera. Ia muncul dari berbagai objek kesadaran seseorang. Ia diyakini benar-benar ada dan mampu membangkitkan semacam reaksi dalam diri seseorang yang kekuatan reaksinya sama dan bahkan bisa lebih kuat daripada reaksi yang dibangkitkan oleh objek-objek inderawinya. Misalnya, ingatan akan sebuah hinaan mungkin bisa membuat diri seseorang lebih marah daripada saat menerima hinaan seperti itu. Begitu juga kita sering merasa lebih malu karena kegagalan-kegagalan kita setelah kita melakukan kegagalan itu, daripada saat kita sedang melakukannya. ${ }^{9}$ Secara umum seluruh sikap moral dan kehidupan keagamaan seseorang lebih banyak didasarkan atas fakta dan gagasan yang tidak tampak seperti ini, daripada berdasar pada rangsangan-rangsangan material yang hadir secara nyata. Seluruh kekuatan pengalaman tersebut secara umum dilaksanakan oleh instrumentalitas dari gagasan-gagasan murni, dan tidak ada sesuatu pun dari pengalaman masa lalu individu yang secara langsung bisa dijadikan model dari gagasan-gagasan tersebut.10

Meskipun objek-objek keagamaan seperti itu dipenuhi oleh berbagai objek abstrak, tetapi ia terbukti memiliki kekuatan pengaruh yang sama, dan bahkan lebih kuat daripada objek-objek konkret yang bersifat empirikmaterial. Ciri-cici Tuhan, kesucian-Nya, keadilan-Nya, belas kasih-Nya, kemutlakan-Nya, ketakberhinggaan-Nya, kemahatahuan-Nya, dan hal-hal lain terkait dengan keberadaan-Nya telah terbukti menjadi sumber melimpah bagi orang-orang yang beragama untuk melakukan meditasi yang memberi inspirasi. Bahkan dalam otoritas mistik, ketiadaan imaji-imaji yang terbatas dan

8 William James, The Varieties of Religious Experience, terj. Gunawan Admiranto, (Bandung: Mizan, 2004), h. 119.

${ }^{9}$ Ibid., h. 120.

10 Ibid.. 
terindera merupakan sine qua non (keniscayaan) demi keberhasilan doa atau kontemplasi tentang kebenaran yang lebih tinggi dari Ilahi.

Objek-objek pikiran sebagaimana tersebut di atas akan membawa kesadaran manusia kepada suatu rasa tentang realitas, perasaaan kehadiran objektif, atau sebuah pencerapan tentang apa yang mungkin disebut sebagai "ada sesuatu" yang lebih mendalam dan umum daripada segala "penginderaan" yang khusus dan tertentu. ${ }^{11}$ Rasa adanya realitas dan perasaan kehadiran objektif seperti ini merupakan sumber dan pondasi bagi keberadaan pengalaman bersua dengan Tuhan.

James menegaskan bahwa meski terkadang banyak orang menafsirkan pengalaman unik kehadiran sesuatu seperti di atas tidak dalam tafsiran secara teistik, yakni dengan istilah kehadiran Tuhan, tetapi tidak ada salahnya untuk menafsirkannya sebagai sebuah bentuk eksistensi dari Ilahi. Yang pasti, menurut James kasus-kasus kehadiran sesuatu seperti di atas telah membuktikan adanya sesuatu di dalam bangunan mental kita yang terkait dengan hadirnya suatu realitas yang bersifat lebih umum dan kabur daripada realitas yang dicerna oleh indera tertentu kita. Meski diakui bahwa para psikolog pun akan merasakan kesulitan dalam melacak kedudukan organik dari perasaan semacam itu. ${ }^{12}$

Tuhan dipandang oleh orang-orang yang mengalaminya terlihat lebih nyata dibandingkan dengan pikiran, segala sesuatu, atau seseorang. Orangorang yang mengalaminya pun merasakan kehadiran-Nya secara positif dan hidupnya pun dirasakan semakin selaras dengan hukum-hukum-Nya. Hal ini merupakan perwujudan dari sebuah hubungan yang intim antara diri seseorang dengan Tuhan sebagai realitas suci yang amat dirasakan menguasa dan menyelimuti dirinya. James menyebutnya sebagai pengalaman nonrasional yang meyakinkan. ${ }^{13}$

Bagaimana pun, pengalaman keagamaan atau pengalaman bersua dengan Tuhan seperti itu berkaitan erat dengan keadaan kehidupan mental dan batiniah yang secara spesifik terdapat bagian yang tidak tersentuh oleh dimensi rasionalitas, dan bahkan menempatkannya dalam level inferioritas.

\footnotetext{
11 Ibid., h. 125.

12 Ibid., h. 131.

13 Ibid., h. 143.
} 
Kalaupun rasionalisme mencoba memasukinya, maka ia hanya mampu menelaah bagian-bagian yang relatif superfisial, yakni pada bagian yang acapkali dianggap memiliki prestise karena mempunyai kefasihan, memberikan bukti, mematahkan logika, serta mengalahkan diri seseorang melalui kata-kata. Akan tetapi, kemampuan rasionalisme seperti itu akan sama sekali gagal untuk meyakinkan atau mengubah pendirian atau keyakinan yang secara jelas telah diperoleh oleh intuisi. James mengatakan,

"Jika Anda memang memiliki intuisi, intuisi ini datang dari level sifatdasar Anda yang lebih dalam daripada level kefsihan kata-kata yang ditempati rasionalisme. Seluruh kehidupan bawah sadar Anda, dorongandorongan hati Anda, iman Anda, kebutuhan Anda, kegiatan Anda untuk mendapatkan pengetahuan akan masa depan, sudah mempersiapkan premispremis yang kemudian dirasakan hasilnya oleh kesadaran Anda. Sesuatu di dalam Anda jelas mengetahui bahwa hasil tersebut pasti lebih benar daripada hasil yang datang dari diskusi adu-logika rasionalistik, betapa pun cerdasnya, yang mungkin bertentangan dengannya."14

Lebih lanjut James menyebutkan:

"Sesungguhnya, dalam lingkup keagamaan atau metafisis, penalaran yang fasih melalui kata-kata akan dapat meyakinkan kita hanya jika perasaan kita tentang realitas yang tidak terkatakan sebelumnya sudah mendapatkan impresi (kesan) yang mengantarkan pada kesimpulan yang sama.... Keyakinan impulsif kitalah yang selalu membentuk struktur kebenaran, dan filsafat yang diverbalkan secara fasih ini hanyalah penerjemahannya ke dalam berbagai perumusan. Keyakinan seketika dan tanpa penalaran adalah hal mendalam pada diri kita, sementara argumen melalui penalaran hanyalah tampilan luarnya. Nalurilah yang memimpin, penalaran hanya mengikuti". ${ }^{15}$

Secara tegas, James mengatakan, "Jika seseorang merasakan kehadiran Tuhan sedemikian nyata, argumen-argumen kritis Anda, meskipun seunggul apa pun, akan tidak berguna dalam mengubah keyakinannya".16 Bukti kuat dari kebenaran keyakinan yang tidak mampu lagi terbantahkan oleh argumen-argumen rasionalisme seperti itu adalah munculnya perasaan

14 Ibid., h. 145.

15 Ibid., h. 146.

16 Ibid. 
antusiasme dan kekhidmatan yang sedemikian kuat dalam diri orang-orang yang religius. Rasa antusiasme dan kekhidmatan seperti itulah yang pada akhirnya mengantarkan seseorang mencapai puncak kebahagiaannya, yakni saat dirinya mencapai kedekatan hubungan yang amat dekat dengan Tuhan atau Realitas gaib yang ia khidmati. Meski terkadang bentuk kekhidmatan tersebut memaksanya untuk berkorban dan hidup dalam penuh ketragisan, tetapi hal itu dalam konteks relasi dengan Realitas Gaib atau Tuhan, dianggapnya sebagai kebaikan dan benar-benar dirasakan memberinya kebahagiaan. Rasa bahagia yang ditimbulkan agama atau persatuan dengan Tuhan seperti itu berbeda jauh dengan makna bahagia secara biologis. Bahkan antara keduanya terlihat bertentangan. Jika kebahagiaan yang ditimbulkan agama terkadang bisa disertai oleh kerelaan untuk berkorban dan hidup penuh penderitaan, tetapi dalam kebahagiaan biologis hal itu ditolak dan dianggap sebagai sesuatu yang salah atau jahat. ${ }^{17}$

Yang pasti, pengalaman bersua dengan Tuhan tersebut terpenuhi oleh perasaan akan kehadiran sesuatu Kekuatan Yang Maha Tinggi (Tuhan) dan penuh dengan suasana penuh akrab, serta penuh gairah. Pengalaman tersebut telah melahirkan perubahan mendadak (konversi) kehidupan mental dan psikologis seseorang. Pengalaman tersebut banyak melahirkan karakter kekudusan dalam diri manusia. ${ }^{18}$ Secara empiris karakter kekudusan tersebut

17 Ibid., h. 152.

18 Karakter kudus adalah sebuah karakter yang didalamnya emosi spiritual menjadi pusatreguler dari energi pribadi. Karakter kekudusan seperti ini, secara umum memiliki ciri-ciri sebagai berikut: (1) perasaan berada di dalam kehidupan yang lebih luas ketimbang kehidupan dunia yang dipenuhi oleh kepentingan-kepentingan sempitnya. Juga adanya sebuah keyakinan tentang adanya Kekuatan Ideal, yang dirasakan sebagai Tuhan sejati. (2) perasaan adanya kesinambungan yang bersahabat antara Kekuatan Ideal dengan kehidupan diri seseorang, serta adanya kesediaan diri untuk berserah diri kepada kendalinya. (3) rasa bahagia dan bebas yang teramat besar, ketika batasbatas yang mengekang diri menjadi luluh. (4) adanya pergeseran pusat-emosional menuju sifat mengasihi dan afeksi-afeksi yang selaras, ke arah kata "ya, ya", dan meninggalkan kata "tidak", yang di dalam kondisi seperti ini klaim-klaim non-egolah yang berperan.

Selanjutnya, kondiri-kondisi batin dari diri yang kudus seperti itu akan memiliki konsekuensi praktis yang khas, sebagai berikut: (a) asketisisme (sikap penyerahan diri yang begitu bersemangat hingga menjadi sikap pengorbanan diri), (b) kekuatan jiwa (perasaan antusiasme yang begitu membahagiaan hingga seluruh motif-motif personal tidak lagi terasa mampu menguasainya, sehingga yang bersangkutan diliputi oleh kesabaran dan keberanian, lenyaplah rasa takut dan kecemasan, dan sebagainya), (c) kemurnian (pergeseran pusat-emosi ke arah keadaan kehidupan spiritual yang murni, hingga berasa dalam keadaan kekudusan secara konstan), dan (d) kasih (meningkatnya kelembutan dan kasih-sayang terhadap sesama makhluk). Lihat dalam William James, ibid., h. 376-377. 
bisa dibuktikan melalui tebaran sikap lembut hati dan kasih dari orang-orang yang tercatat sebagai orang kudus kepada sesama. ${ }^{19}$ Pengalaman seperti ini terlahir dari pengertian agama sebagai individu (personal religion), bukan dari pengertian agama sebagai institusi (institutional religion). Menurut James pengertian agama sebagai persoalan personal seperti ini diartikan sebagai "Segala perasaan, tindakan, dan pengalaman pribadi manusia dalam kesendiriannya, sejauh mereka memahami diri mereka sendiri saat berhadapan dengan apa pun yang mereka anggap sebagai yang ilahiah". 20

Dari sisi personal, agama dipahami sebagai watak batin manusia sendiri yang lebih bersifat pribadi/personal, seperti kesadaran, rasa kesepian, ketidakberdayaan, dan rasa ketidaklengkapan dirinya. Meskipun di dalamnya masih terdapat ciri khusus seperti persoalan pertolongan Tuhan, baik dalam bentuk penebusan atau balasan, serta persoalan teologi yang masih memainkan peran yang penting di dalamnya, akan tetapi semua tindakan yang ditimbulkan oleh keberagamaan seperti ini adalah tindakan personal, bukan ritual. Si individu melakukan transaksi secara pribadi melalui relasi langsung dari hati ke hati, dari jiwa ke jiwa dengan penciptanya. ${ }^{21}$

Berbeda dari pengertian segi personal agama seperti ini, makna agama dari segi institusional, (religion institutional) yang dipahami sebagai realitas keagamaan yang berisikan seperangkat aturan dan praktik-praktik pemujaan dan pengorbanan, berbagai prosedur yang mesti dilakukan dalam relasinya dengan yang Ilahi, teologi dan upacara serta organisasi keagamaan..2 Segi institusional agama seperti ini merupakan salah satu dari dua cabang agama, yakni pertama cabang agama yang lebih memfokuskan perhatiannya pada masalah keilahiahan, dan kedua cabang agama yang lebih memfokuskan pada perhatian manusia terhadap masalah tersebut. Dua hal ini, dibedakan secara tegas oleh James, sehingga pengertian agama sebagaimana dikemukakan James memiliki kekhasan tersendiri. Dengan kata lain, segi personal agama lebih merupakan aktivitas

19 Ibid., h. 383.

20 Ibid., h. 92.

${ }^{21}$ Lihat, ibid., h. 90. lihat juga dalam William James, The Will to Believe and Human Immortality, New York and Chicago: Bob Corbett, 1987, h. 57.

22 William James, The Varieties of Religious Experience, h. 91. 
pra-sadar, pra-rasional, atau imajinasi kreatif individual dalam merespons hal-hal yang dianggap ilahiah. Karena itu, ia kerap kali disebut juga dengan pengalaman awal atau primordial manusia. Sementara, segi institusional agama lebih merupakan refleksi formal keagamaan yang muncul setelah pengalaman awal (primordial) keagamaan muncul. ${ }^{23}$ Dalam segi institusional keagamaan seperti ini citra kritis dogmatis suatu agama tampak dominan. Agama tidak lagi dipahami sebagai pengalaman-pengalaman subjektif yang bersifat terbuka, tetapi berubah menjadi sebuah doktrin yang tertutup. Meminjam istilah Amin Abdullah citra agama institusional seperti itu lebih bersifat dogmatis yang anti kritik ataupun perubahan (ghair qabil li 'l-taghyīr wa'l-niqas). ${ }^{24}$

Sementara, dalam pandangan al-Ghazali puncak pengalaman bersua dengan Tuhan seperti di atas berada dalam pengalaman ma'rifat billāh yang dialami oleh seorang sufi atau 'ārif billāh. Menurutnya, melalui ma'rifat Allah atau pengenalan terhadap Allah SWT, seorang sufi akan menjumpai hakikat realitas-realitas intuitif menjadi tersingkap di hadapannya, dan acapkali tampak berbalikan dengan tata aturan formalitas agama.25 Selain itu, seorang sufi yang telah mencapai ma'rifat Allah niscaya akan mengenal Keesaan Dzat Allah, Keagungan Allah, Kesempurnaan Allah, serta berbagai hakikat kesempurnaan sifat-sifat dan perbuatan-perbuatan Allah SWT. Capaian pengenalannya itu pada gilirannya akan melahirkan sikap dan perilaku keagamaan yang bertingkat-tingkat, sesuai tingkat ketinggian dan kedalaman pengalaman tauhid yang dimiliki.

Al-Ghazali membagi capaian pengenalan seseorang terhadap hakikat realitas Allah tersebut ke dalam empat tingkatan, ${ }^{26}$ yakni sesuai dengan tingkat kedalaman tauhid yang dimiliki. Keempat tingkatan tersebut menurutnya adalah: pertama, capaian pengenalan Allah yang dihasilkan berdasarkan pengalaman tauhid orang-orang munafik, yaitu tauhid orang-orang yang

${ }^{23}$ Lihat dalam Andrew M. Greeley, Religion, a Secular Theory (Agama suatu Teori Sekular), terj. Abdul Djamal Soemole, (Jakarta: Erlangga, 1988), h. 83.

${ }^{24}$ Amin Abdullah, Studi Agama Pertautan antara Normativitas dan Historisitas, (Yogyakarta: Pustaka Pelajar, 1995), h. 40. lihat juga Amin Abdullah dalam, "Problematika Filsafat Modern: Pertautan antara Normativitas dan Historisitas", makalah, (Yogyakarta: Fakultas Ushuluddin, 1995), h. 15 .

25 Lihat al-Taftazani, Sufi dari Zaman ke Zaman, h. 96.

${ }^{26}$ Lihat Abu Hamid al-Ghazali, Ihya' Ulum al-Din, jilid 4 (Indonesia: Maktabah Dar Ihya' alKutub al-'Arabiyah, t.th.), h. 148. 
mengatakan tidak ada Tuhan kecuali Allah, sementara kalbunya masih melalaikan makna ucapannya. Kedua, capaian pengenalan Allah yang diperoleh berdasarkan pengalaman dan kedalaman tauhid orang awam (Muslim pada umumnya), yaitu tauhid seseorang yang membenarkan makna ungkapanungkapan syahadatnya tersebut. Ketiga, capaian pengenalan Allah yang dialami dan dikemukakan berdasarkan pengalaman dan kedalaman tauhid orang-orang al-Muqarrabin (orang-orang yang akrab dengan Allah), yaitu tauhid seseorang yang menyaksikan kebenaran ungkapan syahadat tersebut secara illuminasi, yakni melalui cahaya Yang Maha Benar. Keempat, capaian pengenalan Allah yang dialami dan dikemukakan berdasarkan pengalaman dan kedalaman tauhid penyaksian orang-orang al-șiddīqin (orang-orang yang benar), yaitu tauhid seseorang yang tidak melihat dalam wujud kecuali hal yang tunggal. Capaian pengenalan Allah yang didasarkan pada kedalaman pengalaman tauhid tingkat keempat ini merupakan peringkat yang paling tinggi, karena seseorang yang mencapai tauhid seperti itu tidak lagi melihat segala sesuatu dalam bentuknya jamak tetapi ia melihatnya dari segi yang tunggal. Dan inilah, menurut al-Ghazali, merupakan tujuan tertinggi dari tauhid yang sesungguhnya. ${ }^{27}$

Secara khusus, al-Ghazali menyebut bahwa capaian pengenalan Allah yang didasarkan pada kedalaman pengalaman tauhid para al-șiddīqin seperti itu telah menimbulkan salah pengertian bagi orang-orang yang belum mendapatkan pemahaman yang utuh mengenai hal itu. Sebagian menyebutkan bahwa yang bersangkutan telah mencapai keadaan bersatu (al-ittihād) dengan Allah, sebagian lagi menuturkan telah mencapai hulül, dan bahkan ada yang mengajukan gagasan waḥdat al-wujüd. Tentu masih banyak capaian-capaian pengenalan dengan Allah yang telah diungkapkan oleh tokoh-tokoh lain, dengan berbagai ragam subjektivitasnya.. ${ }^{28}$ Semua itu tidak dapat dilepaskan dari keadaan diri seseorang yang telah mencapai taraf tersingkapnya hijāb yang menutupi antara dirinya dengan hakikat realitas Allah yang sesungguhnya (al-mukashafah). Keadaan diri seseorang yang telah

27 al-Ghazali, Ihya' Ulum al-Din, jilid 4, h. 240. Lihat juga dalam al-Ghazali, Miskat al-Anwar (Miskat Cahaya-Cahaya), terj. Muhammad Baqir, (Bandung: Mizan, 1992), h. 41-56.

28 Misalnya, Syeikh Ahmad Sirhindi menuturkan konsep wahdad al-shuhūd sebagai bentuk capaian tertinggi perjalanan sufi. Lihat Dr. Muhammad Abd. Haq Ansari, terj. Ahmad Nashir Budiman, (Jakarta: Srigunting, 1997), h. 340. 
mencapai taraf mukashafah seperti itu berada dalam keadaan fanä' (tranc), sehingga yang bersangkutan telah kehilangan kesadaran akan dirinya sendiri.

Dalam keadaan fana seperti itulah, menurut al-Ghazali, seorang arif tidak melihat yang selain Allah serta dia tidak tahu yang selain-Nya. Yang dia tahu dalam wujud ini hanyalah Dia dan kreasi-kreasi-Nya. Dalam keadaan seperti itu dia tidak melihat sesuatu sebagai kreasi semata kecuali bahwa dia justru melihat Kreatornya dan dia mengabaikan kreasi-kreasi tersebut dengan predikat-predikatnya seperti langit, bumi, hewan, atau pohon tetapi sebaliknya dia melihat kesemuanya itu sebagai kreasi Dzat Yang maha Esa lagi Maha Benar. Dalam keadaan seperti ini, seorang arif adalah orang yang benar-benar mencintai Allah dan mengesakan-Nya. Karena baginya, tidak ada yang ia lihat kecuali Allah, tidak ada yang dicintai kecuali Allah. Bahkan dia tidak memandang dirinya dari segi dirinya sendiri, tapi dari segi predikatnya sebagai hamba Allah.

Inilah yang dimaksudkan dengan istilah fana dalam tauhid atau dari dirinya sendiri menurut al-Ghazali. Keadaan fana tersebut, menurutnya, bukan sebagai tujuan akhir dari perjalanan seorang arif, tetapi ia merupakan buah dari pengetahuan atau merupakan salah satu tingkatan ilmu mukashafah, yang telah banyak menimbulkan kesalahpahaman dan kekeliruan bagi para pendukung dan penolaknya. Dalam keadaan fana, seorang sufi atau arif sering mengalami pengalaman kesatupaduan antara yang tunggal dengan yang jamak. Tetapi kesatupaduan yang dimaksudkan tersebut, menurut al-Ghazali bukan kesatupaduan yang bercorak eksistensial, tetapi berdasarkan penyaksian atau kesadaran yang berlangsung pada diri seorang sufi sewaktu dalam keadaan fana. ${ }^{29}$ Artinya, ketika seorang sufi memasuki keadaan fana, maka pada saat seperti itu menjadi tersingkaplah hijāb yang selama ini menutupi dirinya dengan Tuhannya dan seketika itu ia menyaksikan kebenaran Realitas Tuhan yang menakjubkan. Bahkan, karena takjub seperti itu sebagian dari kaum șiddīqin tidak sanggup melepaskan diri dari keterbuaian pengalaman spiritual yang mengasyikkan hingga tanpa disadari keluar katakata aneh (shațahat) dari bibirnya. Seperti itulah yang terjadi. Bagi al-Ghazali pengalaman yang terjadi dalam keadaan $f a n \bar{a}^{\prime}$ seperti itu tidak bisa ditentukan benar-salahnya.

${ }^{29}$ Lihat al-Taftazani, Sufi dari Zaman ke Zaman, h. 177. 
Al-Ghazali menyebutkan bahwa, para kaum 'ārif billāh (orang yang mengalami pengenalan atau penyaksian terhadap Allah) bersepakat bahwa ketika pendakian mereka mencapai puncak, mereka bersepakat bahwa mereka tidak melihat dalam wujud ini kecuali Yang Maha Tuggal lagi Maha Benar. Hanya saja, bagi kaum 'ārif yang mengalami keadaan bersua dengan Allah seperti itu, atau memiliki pengalaman bersatu seperti itu, dengan mendasarkan pada pondasi żauq dan ḥăl, maka seringkali ia tenggelam dalam pengalaman ketunggalan. Sehingga, ketika mereka kehilangan kekuasaan akalnya, maka kata-kata shațahat seperti di atas muncul. ${ }^{30}$

Menurut al-Ghazali, Tuhan yang sedemikian Agung, Maha Sempurna dan Maha Segalanya memiliki tujuh puluh hijāb (tabir penutup) cahaya dan kegelapan, bila dipandang dari segi pandangan para makhluk-Nya. Seandainya Ia menyibakkannya, niscaya cahaya-cahaya wajah-Nya akan membakar siapa saja yang memandang-Nya. ${ }^{31}$ Sebagian makhluk ada yang terhijab oleh kegelapan murni semata-mata, sebagian terhijab oleh cahaya yang bercampur dengan kegelapan, dan sebagian lagi ada yang terhijab oleh cahaya murni semata-mata. ${ }^{22}$ Orang-orang yang masuk kategori terhijab oleh kegelapan murni tersebut adalah orang-orang mulhid (ateis) yang tidak beriman kepada Allah dan hari akhir, yang lebih mengutamakan dunia di atas kehidupan akherat. Termasuk dalam kelompok ini adalah orang-orang yang sangat ingin mencari penyebab adanya dunia dan segalanya, lalu ia mengalihkannya kepada apa yang disebut sebagai "nature (alam)" sebagai penyebab terwujudnya segala sesuatu. Selain itu, termasuk juga orang-orang yang disibukkan oleh dirinya sendiri dan karena itu tidak sempat mempertanyakan tentang penyebab terwujudnya alam semesta ini.33 Sedangkan orangorang yang termasuk dalam kategori terhijab oleh cahaya yang bercampur

${ }^{30}$ Di antara sufi yang mengeluarkan kata-kata aneh seperti ini antara lain adalah Mansur alHallaj, Abu Yazid al-busthami, Ibn 'Arabi, dan lain-lain. Ucapan-ucapan eneh yang mereka ucapkan itu seringkali menyebabkan mereka dituduh telah keluar dari Islam. Mereka pun harus rela menerima hukuman. Lihat, Dr. Kautsar Ashari Noer, Ibn al-'Arabi Wahdat al-Wujud dalam Perdebatan, (Jakarta: Paramadina, 1950), h. 127, lihat juga Shayk Ibrahim Gazur-i-Ilahi, Menyingkap Misteri Sufi Besar Mansur al-Hallaj “Anal Haqq”, (Jakarta: Srigunting, 2000), h. 44.

31 Pandangannya seperti ini didasarkan pada sebuah hadits Nabi yang menyatakan ( إن له سبعين حجابا من نور وظلمة لو كثفها لأحرقت سبحات وجهه كل من أنركه بصره ). Bahkan dalam riwayat lain disebutkan bahwa hijab yang menutupi rahasia Allah tersebut berjumlah "tujuh ratus" dan ada yang menyebutkan "tujuh puluh ribu" hijab. Lihat, al-Ghazali, Miskat al-Anwār, h. 95

32 Ibid, h. 96

${ }^{33}$ Lihat, ibid, h. 97. 
dengan kegelapan, mereka itu terdiri dari: (1) orang-orang yang kegelapannya berasal dari indera mereka; (2) orang-orang yang kegelapannya berasal dari daya khayal mereka, dan (3) orang-orang yang kegelapannya bersumber dari kesimpulan-kesimpulan akal berdasarkan perkiraan-perkiraan analogis yang keliru. ${ }^{34}$

Adapun yang tergolong dalam kategori orang-orang yang terhijab oleh cahaya-cahaya murni adalah mereka-mereka yang tergabung dalam berbagai aliran yang ada, yang jumlahnya amat banyak sekali. Beberapa golongan yang termasuk dalam kategori ini adalah: (1) orang-orang yang benar-benar telah mengetahui makna sifat-sifat yang dikaitkan dengan Allah swt. berdasarkan pentahkikan; (2) orang-orang yang pikirannya lebih maju dan tingkatannya lebih tinggi dari yang sebelumnya, yakni mereka yang menyadari tentang adanya kemajemukan di lelangit, dan bahwa "penggerat" setiap langit secara khusus adalah makhluk lain yang disebut malaikat; (3) orang-orang yang tingkatannya lebih tinggi dari kelompok sebelum ini, yakni mereka yang beranggapan bahwa perbuatan menggerakkan benda-benda secara langsung sepatutnya merupakan suatu bentuk pelayanan untuk Rabb al-'Alamin, ibadat kepada-Nya serta ketaatan seorang hamba di antara hamba-hambaNya, dan (4) adalah orang-orang yang telah sampai di akhir perjalanan (alwașilun) dan beranggapan bahwa al-muța' (yang ditaati) bagaimanapun masih memiliki suatu sifat yang berlawanan dengan keesaan murni dan kesempurnaan yang mutlak disebabkan oleh suatu rahasia yang tersembunyi.35

Selanjutnya al-Ghazali pun menjelaskan bahwa kelompok yang keempat, yakni golongan orang-orang yang telah sampai perjalanan akhir tersebut masih terbagi lagi ke dalam beberapa bagian. Sebagian ada yang mengalami keadaan $f a n \bar{a}^{36}$ yang menyebabkan terbakarnya segala yang pernah dicerap

\footnotetext{
34 Penjelasan tentang orang-orang yang termasuk dalam kelompok ini secara panjang lebar dalam di lihat dalam ibid., h. 101.

35 Lihat, ibid., h. 111.

36 Yang dimaksud dengan fanā' dalan terminology tasawuf adalah penafian atau peniadaan diri saat terjadi penyatuan antara diri dan Tuhan. Ketika melakukan perjalanan menuju Allah (Sumber yang dituju), sang murid akan melewati berbagai tingkatan fanā' yang masing-masing mendekatkan diri pada Yang dituju (Allah). Dalam disiplin tasawuf, fan̄̄' ini memiliki tiga tipe yang mesti akan dilalui oleh seseorang yang menginginkan tercapainya "kedekatan" dengan Yang Maha Mutlak, yaitu fanā' fi murshid, fanā' fi 'l-rasūl dan fanā' fi Allāh. Lihat, Amatullah Armstrong, Sufic Terminology. h. 66. Sementara menurut al-Taftazani istilah fanā' tersebut dalam kalangan sufi diartikan dengan berbagai ragam pengertian. Pertama, term fană' diartikan sebagai keadaan moral
} 
oleh penglihatannya, lalu ia sendiri menjadi larut dan luluh kendati masih terus menatap "Keindahan" dan "Kekudusan" di samping menatap dirinya sendiri dalam "Keindahan" yang diraihnya dengan telah mencapai Hadrat Ilāhiyyah. Dengan demikian, menjadi luluhlah segala yang dapat terlihat di hadapan Yang Maha Melihat. Sebagian lagi terdapat kelompok khawāṣ alkhawāș, yakni kelompok orang-orang yang khusus di antara yang khusus. Mereka ini telah "terbakar" oleh cahaya-cahaya wajah-Nya yang Tertinggi lalu tenggelam dalam gelombang "Kekuatan Keagungan", sehingga diri mereka larut dan luluh sama sekali. Karena itu pula, mereka tidak lagi memiliki perhatian sedikit pun ke arah diri mereka sendiri disebabkan kefanaan diri mereka itu. Di saat seperti itu tiada sesuatu pun yang masih tertinggal kecuali Yang Maha Tunggal lagi Maha Benar. Dalam keadaan seperti ini pula, sebagian para sufi ada yang menyebut telah mengalami ittihăd, sebagian lagi menyebutnya dengan hulūl, dan sebagian lagi menyatakan mengalami kefanaan dalam tauhid.

Begitulah, gambaran tentang pengalaman bersua dengan Tuhan dalam pandangan para sufi yang dicoba dielaborasi al-Ghazali melalui konsepnya tentang ma'rifat yang dalam kenyataannya memiliki tingkat kedalaman seiring kedalaman pengalaman masing-masing sufi serta tingginya maqam yang dicapai. Yang pasti, berbagai pengalaman seperti itu akan memberikan suatu kondisi kalbu yang tenteram (al-țma'ninah).

yang luhur, sebagaimana terlihat dalam pendapat para sufi yang mengartikan fanā' sebagai "fanā'nya sifat jiwa," "sirnanya sifat-sifat yang tercela," atau "terbebaskannya diri dari hal-hal yang bersifat duniawi". Kedua, fanā' diartikan sebagai kesirnaan manusia dari kehendaknya yang umum dan kekekalan kehendaknya dengan kehendak Allah, seperti yang terlihat dalam pendapat al-Thusi dan al-qusyairi. Ketiga, fanā' diartikan sebagai kesirnaan diri dari perhatian (penyaksian) terhadap halhal yang normal, yang menimbulkan rangsangan (syahwat) atau keinginan makhluk. Keempat, fana ${ }^{\prime}$ dalam arti khusus (mistik) sebagaimana sering disebut oleh sebagian sufi, diartikan sebagai hilangnya perasaan dan kesadaran dimana seorang sufi tidak lagi merasakan apa yang terjadi pada organ-organ tubuhnya, tidak pula dirinynya dan alam sekitar yang luas. Kondisi seperti ini, menurut al-Qusyairi, meskipun tetap tidak mungkin menapikan eksistensi dirinya dan juga segenap makhluk yang ada disekitarnya, namun secara psikologis, sufi tersebut lupa terhadap dirin dan semua makhluk yang ada, dan bahkan dia tidak merasakan eksistensi dirinya dan semua makhluk. Dengan bahasa psikologi modern, dikatakan bahwa fană' merupakan kondisi intuitif, dimana seseorang untuk beberapa lama kehilangan perasaannya terhadap ego, yang dalam terminologi para sufi hal iu berarti, "Ketidaksadaran seseorang terhadap dirinya maupun hal-hal yang berkaitan dengannya". Lihatal-Taftazani, Sufi dari Zaman ke Zaman, h. 106-108. 


\section{Konstruksi Epistemologis Antara Pemikiran William James dan al-Ghazali tentang Pengalaman Bersua dengan Tuhan}

Persoalan pengalaman manusia bersua dengan Tuhan bukan saja menjadi monopoli disiplin tasawuf atau mistik yang telah berkembang sedemikian lama, tetapi ia merupakan sebuah fenomena yang membuat disiplin-disiplin lain tertarik untuk mengkajinya. Salah satu disiplin ilmu, yang secara metodologi berbasis ilmiah, tertarik untuk menyingkapnya adalah disiplin psikologi. Salah satu tokoh terpentingnya adalah William James. Ia secara konsisten telah berusaha menunjukkan bahwa persoalan pengalaman keagamaan, dan secara khusus persoalan pengalaman bersua dengan Tuhan, merupakan persoalan yang patut ditelusuri berdasarkan kaidah-kaidah ilmiah sebagaimana yang dipegangi secara umum oleh para penganut ilmu ini.

Dalam tradisi Islam, persoalan tentang pengalaman bersua dengan Tuhan seperti itu banyak dikaji dalam tradisi tasawuf, yang salah satu tokoh terkenalnya adalah al-Ghazali. Kehadiran al-Ghazali telah berhasil menengahi pertentangan yang terlihat tajam antara pendukung ortodoksi, yang lebih mengedepankan aspek eksoteris agama dengan penganut heterodoksi yang lebih mengutamakan dimensi esoteris agama. Persoalan pengalaman bersua dengan Tuhan, yang lebih kental bernuansa isoteris, berhasil dijembatani alGhazali sedemikian baik, hingga gagasan-gagasan tasawuf kembali bisa diterima oleh para penganut ortodoksi Islam.

Apa yang dilakukan William James dan al-Ghazali tersebut tampaknya perlu dikaji atau dicermati lebih lanjut. William James berusaha menunjukkan arti penting serta keabsahan persoalan pengalaman keagamaan serta pengalaman bersua dengan Tuhan sebagai salah satu kajian dalam disiplin psikologi, sementara al-Ghazali berusaha menyingkap kebenaran pengalaman puncak keberagamaan atau pengalaman bersua dengan Tuhan tersebut berdasar bingkai tata aturan syari'at, sebagaimana dipegangi oleh para pendukung ortodoksi. Apa yang dilakukan oleh James tersebut pada dasarnya berusaha memberikan dasar-dasar kuatifikasi terhadap fenomena pengalaman keagamaan, terutama pengalaman bersua dengan Tuhan, sebagai fakta yang tidak bisa dinegasikan. Begitu juga, apa yang dilakukan oleh al-Ghazali tersebut adalah berusaha membuktikan bahwa pengalaman bersua dengan Tuhan sebagaimana dikemukakan oleh sebagian tokoh sufi yang ada merupa- 
kan kebenaran yang dibenarkan pula oleh syari'at agama. Bahkan ia bisa membuktikan kebenarannya berdasarkan argumentasi rasional ataupun ketajaman batin seseorang. Hanya saja, titik pijakan serta konstruk landasan epistemologis dari kedua tokoh tersebut tampak terdapat perbedaan. William James berpijak pada landasan epistemologis disiplin ilmu psikologi, sementara al-Ghazali berpijak pada landasan epistemologis disiplin ilmu tasawuf (sufism).

Dalam konstruk epistemologis James, keberadaan pengalaman keagamaan yang berupa pengalaman bersua dengan Tuhan seperti di atas memiliki dasar berpijak pada fakta keberadaan dorongan dan perasaan religius setiap manusia. Fakta tersebut dijadikan dasar oleh James dan juga diakui oleh para psikolog lainnya untuk melakukan penelitian lebih lanjut mengenai kecenderungan-kecenderungan religius seperti itu. James sendiri berusaha melakukan pembatasan secara metodologis terhadap fakta-fakta dorongan dan perasaan religius tersebut sebatas pada keberadaan dokumen insani (documents humans), ${ }^{37}$ yang ia bagi ke dalam dua dimensi penyelidikan, yakni dimensi fakta kecenderungan religius dan dimensi nilai atau signifikansinya. Dari penyelidikan terhadap dimensi pertama akan menghasilkan preposisi atau "penilaian eksistensial" (existential judgement), sedangkan dari penyelidikan terhadap dimensi kedua akan menghasilkan "proposisi nilai" (proposition of value) atau "penilaian spiritual" (spiritual judgement). ${ }^{38}$ Kedua penyelidikan ini menurut James, sebaiknya dipadukan, yakni dengan menggabungkan "penilaian spiritual" dan "penilaian eksistensial". ${ }^{39}$

37 William James, The Varieties of Religious Experience, p. 61.

38 Ibid., p. 63.

39 Terkait contoh yang membedakan dua tatanan penyelidikan ini, James memberikan cintoh fenomena al-Kitab dalam tradisi agama kristen. Menurutnya telaah terhadap al-Kitab tidak cukup dari sudut penyelidikan eksistensialnya saja, meski hal ini masih sangat kurang dilakukan dalam tradisi gereja zaman dahulu. Akan tetapi, perlu juga melakukan penyelidikan dengan memakai sudut pandang yang lain, yaitu dengan memakai penilaian spiritual. Tidak hanya ditelaah mengenai kondisi biografis apa saja dari para rasul yang memberikan berbagai sumbangan kepada al-Kitab tersebut? Juga tidak hanya menelaan tentang apa sebetulnya yang ada dalam pikiran individual mereka saat mereka merisalahkannya? Akan tetapi telah terhadap al-kitab tersebut juga berkaitan dengan persoalan atau pertanyaan tentang apa gunanya al-Kitab itu sebagai pedoman hidup dan wahyu bagi diri seseorang atau kita? Meskipun demikian, menurut James kedua model penyelidikan tersebut bisa dipadukan, yakni dengan menggabungkan "penilaian spiritual" dan "penilaian eksistensial". Dengan demikian, jika teori nilai wahyu (theory of revelation-value) ini menetapkan bahwa suatu kitab supaya dianggap memiliki nilai-wahyu, tidak boleh memiliki kesalahan historis atau ilmiah apa pun, dan harus disusun secara otomatis, yakni tidak berdasarkan perubahan-pikiran 
Berdasarkan penyelidikannya tersebut, James menemukan kenyataan bahwa meski pengalaman-pengalaman religius seperti itu memiliki ciri patologis, tetapi justeru hal itu telah memberi pengaruh positif dan otoritas keagamaan yang luar biasa bagi orang-orang yang mengalaminya. ${ }^{40}$

Pengalaman religius seperti itu, dalam beberapa kasus juga telah memberikan otoritas dan pencerahan batin yang luar biasa. ${ }^{41}$ Bukan saja bisa dirasakan oleh orang-orang yang mengalaminya saja, tetapi juga oleh orangorang yang berada disekelilingnya. Akan tetapi fakta kebenaran pengalaman religius seperti itu, menurutnya, harus diuji melalui logika dan eksperimen, tanpa melihat tipe neurologi pencetusnya. ${ }^{42}$ Tolok ukur yang dijadikan landasannya didasarkan pada dua penilaian, yakni pertama, didasarkan pada perasaan yang muncul seketika dalam diri kita, dan kedua, didasarkan pada apa yang bisa kita yakini tentang hubungan eksperiensialnya dengan kebutuhan moral kita dan pada hal-hal yang kita anggap benar. ${ }^{43}$ Selanjutnya, nilai kebenaran pengalaman tersebut diukur berdasarkan tiga kriteria kebenaran, yaitu keterpahaman langsung (immediate luminousness), kemasukakalan filosofis (philosophical reasonableness), dan kegunaan moral (moral helpfulness). ${ }^{44}$ Secara sederhana, konstruk epistemologi yang dikembangkan William James terkait penyelidikannya terhadap pengalaman religius seperti ini dapat digambar sebagai berikut:

mendadak seorang penulis dan tidak menampilkan nafsu pribadi, maka definisi al-Kitab seperti itu tidak akan lulus uji-kelayakan berdasarkan perspektif psikologi. Namun, jika ia mengizinkan kita untuk menganggap sebuah kitab sebagai wahyu meskipun tidak luput dari kesalahan dan nafsu insani, serta disusun dengan sengaja oleh manusia, asalkan merupakan sebuah catatan asli tentang pengalaman-pengalaman batin orang-orang berjiwa besar yang berjuang melawan krisis dalam hidup mereka, maka penilaian kita terhadap al-Kitab tersebut akan lebih baik. Dalam kenyataannya, fakta-fakta eksistensial itu sendiri tidak mencukupi untuk menentukan nilai kesucian suatu kitab. Berdasarkan kenyataan ini pula, banyak ahli yang berusaha menghindari kerancuan yang ditimbulkan oleh dua penyelidikan tersebut, demi untuk mempertahankan pengertian mereka tentang nilai kesucian wahyu. Berdasarkan kesimpulan-kesimpulan yang sama atas suatu fakta, mereka kemudian membangun pandangan yang berbeda tentang nilai al-Kitab sebagai wahyu, sesuai dengan perbedaan "penilaian spiritual" dan landasan nilai mereka. Lihat William James, ibid., p. 63-64.
40 Ibid., p. 66.
41 Ibid., p. 75.
42 Ibid., p. 77.
43 Ibid..
${ }^{4}$ Ibid. 


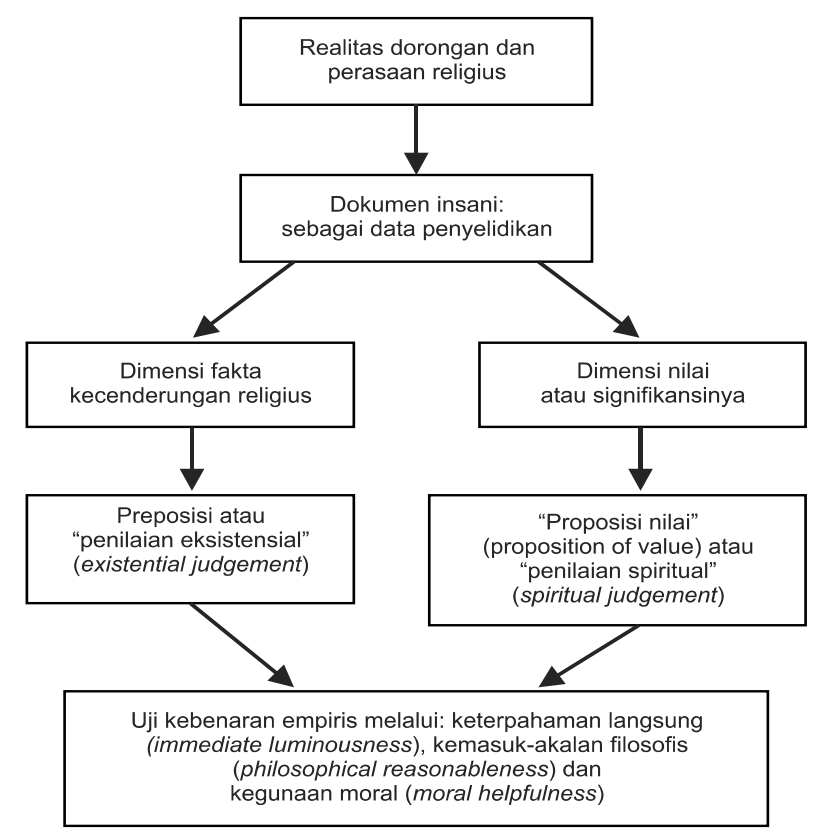

Gambar 1.

Konstruk Epistemologi William James terhadap Pengalaman Religius

Sementara itu, konstruk epistemologis yang hendak dibangun oleh alGhazali lebih didasarkan pada hati, intuisi, atau gnosis sebagai satu-satunya sumber pengetahuan yang benar. Al-Ghazali dalam batas-batas tertentu masih mempercayai potensi kebenaran informasi yang diperoleh berdasarkan cerapan inderawi manusia ataupun rasio manusia. Akan tetapi, untuk memahami kedalaman pengalaman bersua dengan Tuhan, potensi inderawi dan rasio manusia tidak sepenuhnya dapat diandalkan. Menurut al-Ghazali inderawi memiliki paling tidak tujuh kelemahan, yaitu: (1) ia tidak bisa melihat dirinya sendiri, meski bisa melihat benda-benda lain; (2) ia tidak dapat melihat sesuatu yang amat jauh ataupun yang amat dekat; (3) ia tidak dapat mencerap benda-benda yang berada di balik selubung; (4) ia hanya dapat mencerap bagian permukaan sesuatu dan bukan bagian dalamnya; (5) ia hanya dapat melihat sebagian kecil dari mawjūd saja dan bukan keseluruhan- 
nya; (6) ia hanya mampu mencerap sesuatu yang terhingga (terbatas) dan tidak mampu melihat sesuatu yang tidak terhingga, dan (7) ia banyak melakukan kesalahan ketika melihat sesuatu, terkadang sesuatu yang besar tampak kecil dalam penglihatan dan begitu juga sebaliknya. ${ }^{45}$

Begitu juga akal atau rasio manusia, meski keberadaannya bisa dijadikan sebagai mīzān (neraca) Allah ${ }^{46}$ serta neraca penilai (hakim) terhadap berbagai ragam pengalaman puncak religius, dalam banyak hal ia bukan sebagai sumber yang mampu memberikan kebenaran yang sesungguhnya, terutama pengetahuan yang berkaitan dengan pengalaman spiritual manusia. Akal hanya memiliki kemampuan untuk menyusun dalil-dalil logis yang bisa memberikan kebenaran-kebenaran yang bersifat logis. Sementara, realitas kebenaran yang sesungguhnya bukan saja terbatas pada kebenaran-kebenaran yang bersifat logis.

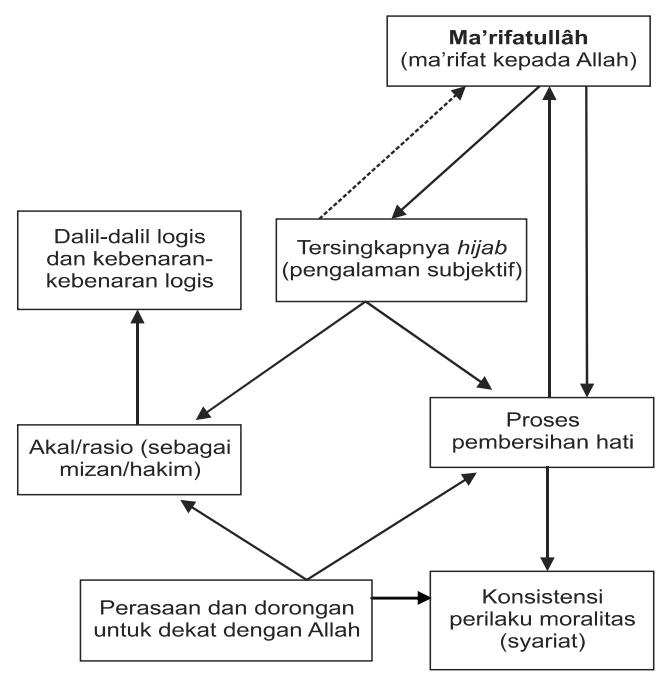

Gambar 2.

Konstruk Epistemologi al-Ghazali terhadap

Pengalaman Religius

${ }^{45}$ Lihat al-Ghazali, Miskat al-Anwār, h. 18-25.

46 Lihat ibid., h. 42. 
Menurut al-Ghazali hakikat kebenaran yang hakiki adalah berupa limpahan cahaya kebenaran dari Tuhan yang disematkan ke dalam hati sanubarinya. Melalui ketersingkapan (al-mukashafah) atau pencerahan (illuminasi) seperti itulah berbagai hijāb serta pintu-pintu ilmu pengetahuan menjadi terbuka sedemikian luar biasa. ${ }^{47}$ Secara sederhana, konstruk epistemologi menurut al-Ghazali seperti ini dapat dilihat pada gambar di atas.

Meski al-Ghazali menekankan kalbu sebagai sumber utama untuk mendapatkan kebenaran yang hakiki, yakni berupa limpahan cahaya kebenaran Tuhan melalui terbukanya tabir penutup kegelapan, bukan berarti ia mengabaikan arti penting bukti-bukti empiris berupa predikat-predikat moralitas yang baik. Sama sekali tidak demikian. Justeru sikap konsistensi terhadap aturan moralitas yang berdasarkan ketentuan syari'at itulah merupakan inti bagi proses pembersihan hati, baik melalui proses takhalli, tahalli, hingga akhirnya memasuki proses tajallī. Dengan demikian, secara epistemologis alGhazali sama sekali tidak mengabaikan arti penting fakta-fakta perilakuperilaku empirik (sharīat) sebagai kunci dan sarana tercapainya dorongan untuk ma'rifatullāh.

Jika kedua konstruk tersebut diperbandingkan, akan terlihat seperti berikut:

Tabel 1.

Perbandingan antara Konstruk Epistemologi William James dan al-Ghazali terhadap Pengalaman Religius

\begin{tabular}{|l|l|l|l|}
\hline No. & \multicolumn{1}{|c|}{ Materi } & \multicolumn{1}{|c|}{ William James } & \multicolumn{1}{c|}{ al-Ghazali } \\
\hline 1. & $\begin{array}{l}\text { Pilihan disiplin } \\
\text { keilmuan }\end{array}$ & $\begin{array}{l}\text { Disiplin Psikologi dan } \\
\text { konsisten pada prinsip- } \\
\text { prinsip metodologi ilmiah } \\
\text { yang merupakan basis } \\
\text { dari disiplin psikologi. }\end{array}$ & $\begin{array}{l}\text { Pada awalnya merupakan } \\
\text { penjelajah multidisipliner, } \\
\text { tetapi setelah sembuh } \\
\text { dari sakit skeptis akhirnya } \\
\text { menjatuhkan pilihan pada } \\
\text { tasawuf atau gnosis } \\
\text { hingga akhir ajalnya. }\end{array}$ \\
\hline 2. & $\begin{array}{l}\text { Pola epistemo- } \\
\text { logi }\end{array}$ & $\begin{array}{l}\text { Berbasis epistemologi } \\
\text { burhani. } \\
\text { Sumber kebenaran }\end{array}$ & $\begin{array}{l}\text { Berbasis epistemologi } \\
\text { irfani. } \\
\text { Sumber kebenaran }\end{array}$ \\
\hline
\end{tabular}

${ }^{47}$ Ibid., h. 31. 


\begin{tabular}{|c|c|c|c|}
\hline & & $\begin{array}{l}\text { berbasis pengalaman } \\
\text { empirik. }\end{array}$ & $\begin{array}{l}\text { berbasis pada hati atau } \\
\text { gnosis }\end{array}$ \\
\hline 3. & $\begin{array}{l}\text { Penekanan } \\
\text { metodologi } \\
\text { yang dipilih }\end{array}$ & $\begin{array}{l}\text { menerapkan prinsip- } \\
\text { prinsip metode ilmiah. } \\
\text { selalu merujuk pada } \\
\text { pengalaman empirik } \\
\text { sebagai sumber } \\
\text { kebenaran. } \\
\text { Uji kebenaran melalui uji } \\
\text { empirik dan ujia logis- } \\
\text { rasional. }\end{array}$ & $\begin{array}{l}\text { konsisten dengan } \\
\text { metodologi keilmuan } \\
\text { tasawuf atau gnosis. } \\
\text { lebih mengedepankan } \\
\text { proses pembersihan hati } \\
\text { sebagai alat untuk } \\
\text { mendapatkan } \\
\text { pengetahuan yang benar. } \\
\text { Menguji kebenaran } \\
\text { melalui proses perjalanan } \\
\text { rohani dengan melewati } \\
\text { proses takhali, tahalli, } \\
\text { dan tajalli. }\end{array}$ \\
\hline 4. & $\begin{array}{l}\text { Ide tentang } \\
\text { agama }\end{array}$ & $\begin{array}{l}\text { agama dalam pengertian } \\
\text { personal, bukan } \\
\text { institusional } \\
\text { agama sebagai faktor } \\
\text { neurologis }\end{array}$ & $\begin{array}{l}\text { agama dalam pengetian } \\
\text { institusional } \\
\text { Agama sebagai hidayah, } \\
\text { anugerah, serta fitrah suci }\end{array}$ \\
\hline 5. & $\begin{array}{l}\text { Ide tentang } \\
\text { Tuhan }\end{array}$ & $\begin{array}{l}\text { Tidak memperjelas makna } \\
\text { Sesuatu yang dianggap } \\
\text { llahi. } \\
\text { melahirkan perubahan } \\
\text { mendadak (konversi) } \\
\text { kehidupan mental dan } \\
\text { psikologis seseorang. }\end{array}$ & $\begin{array}{l}\text { Secara tegas dan jelas } \\
\text { menyebut Allah sebagai } \\
\text { ide tentang Tuhan } \\
\text { Melahirkan kerinduan } \\
\text { dan keinginan untuk } \\
\text { mendekati dan } \\
\text { memahami-Nya }\end{array}$ \\
\hline 6. & $\begin{array}{l}\text { Sifat dan } \\
\text { karakteristik } \\
\text { kajian }\end{array}$ & $\begin{array}{l}\text { sekedar menyingkap, } \\
\text { mendeskripsi, serta } \\
\text { melakukan penilaian serta } \\
\text { uji kebenaran fakta-fakta } \\
\text { kecenderungan religius } \\
\text { seseorang. }\end{array}$ & $\begin{array}{l}\text { berbicara banyak } \\
\text { mengenai cara manusia } \\
\text { menjadi dekat dengan } \\
\text { Allah, serta menjadi } \\
\text { manusia yang mampu } \\
\text { mencapai derajat } \\
\text { kema'rifatan yang tinggi. }\end{array}$ \\
\hline
\end{tabular}

Namun demikian, ada sisi-sisi kesamaan yang ditunjukkan oleh kedua tokoh tersebut, yaitu: (1) Sama-sama mengakui keberadaan perasaan dan dorongan religius dalam diri manusia, yang oleh al-Ghazali disebut sebagai dorongan fitrah manusia. (2) Sama-sama mengakui bahwa pegalaman bersua dengan Tuhan mampu menimbulkan keadaan-keadaan kejiwaan atau 
psikologi mengalami ekstase religius, antusiasme moral, ketakjuban ontologis, dan emosi-kosmik. (3) Sama-sama memiliki perhatian pada persoalan fenomena pengalaman mistik. Hanya saja James konsisten dengan metodologinya, sehingga hanya sebatas membuktikan serta menguji kebenarannya. Sementara al-Ghazali langsung memberikan panduan untuk mengalami dan memasukinya secara langsung. (4) Sama-sama membawa semangat misi untuk menjelaskan bahwa fenomena pengalaman keagmaan terlebih pengalaman bersua dengan Tuhan merupakan fakta kebenaran yang layak menjadi kajian masing-masing disiplin yang ditekuni. (5) Sama-sama mengakui adanya dimensi-dimensi kedahsyatan, kekhidmatan, serta kebahagiaan, dan juga adanya buah-buah moralitas yang baik, yang dimunculkan oleh pengalaman bersua dengan Tuhan seperti itu.

Untuk bisa menunjukkan keakurasian kebenaran pengalaman religius seperti itu, terutama pengalaman bersua dengan Tuhan yang cenderung bersifat unik dan subjektif, perlu mengkompromikan kedua pendekatan di atas. Tampaknya tidak cukup hanya menggunakan pendekatan tasawuf atau irfani untuk mengetahui kebenaran pengalaman religius beserta buah-buahnya tersebut. Begitu juga, rasanya akan banyak hal yang menjadi tidak tersentuh bila untuk mengungkapkan relitas pengalaman spiritual seperti itu hanya memakai pendekatan psikologi, sebagaimana dilakukan oleh James. Memang, banyak bukti-bukti ilmiah yang bisa terbukakan, tetapi dengan hanya menerapkan metode dan pendekatan psikologi saja tidak mampu menyingkap keunikan dari fenomena pengalaman keagamaan tersebut.

Meminjam klasifikasi James, penerapan metodologi atau pendekatan tasawuf, irfani, atau gnosis tersebut akan semakin memperkokoh pengakuan kebenaran sumber atau asal-usul pengalaman keagamaan tersebut, yang berdasarkan analisa pendekatan psikologi serap diragukan kebenarannya. Tidak sedikit tokoh-tokoh psikologi yang menganggap sumber pengalaman religius seperti itu bersifat non-rasional. James sendiri mengakui bahwa berdasarkan kriteria sumbernya, pengalaman keagamaan seperti itu memiliki gejala-gejala neurosis, tetapi buah-buah moral yang dihasilkannya dalam kenyataannya jauh lebih riil ketimbang pengalaman inderawi sendiri. Begitu juga, penerapan metodologi atau pendekatan psikologi akan dapat dipakai untuk melihat tingkat akurasi keilmiahan dari buah-buah pengalaman tersebut. 


\section{Kesimpulan}

Dalam pandangan William James pengalaman bersua dengan Tuhan tidak bisa dipisahkan dari keberadaan pengalaman keagamaan yang yang bersifat personal. Dalam pengalaman bersua dengan Tuhan tersebut terpenuhi oleh perasaan akan kehadiran sesuatu Kekuatan Yang Maha Tinggi (Tuhan) dan penuh dengan suasana penuh akrab, serta penuh gairah, hingga mampu melahirkan perubahan mendadak (konversi) kehidupan mental, psikologis dan melahirkan karakter kekudusan dalam diri manusia. Secara empiris karakter kekudusan tersebut bisa dibuktikan melalui tebaran sikap lembut hati dan kasih dari orang-orang yang tercatat sebagai orang kudus kepada sesama. Pengalaman bersua dengan Tuhan seperti itu dalam pandangan al-Ghazali tercapai dalam bentuk ma'rifat billāh. Melalui ma'rifat billāh inilah seseorang akan mengalami perbedaan tingkat pengenalan terhadap Allah sesuai tingkat kedalaman pengalamannya, yang oleh al-Ghazali disebutkan ada empat tingkatan, yaitu pertama, berdasarkan pengalaman tauhid orang-orang munafik, kedua, berdasarkan pengalaman dan kedalaman tauhid orang awam (Muslim pada umumnya), ketiga, berdasarkan pengalaman dan kedalaman tauhid orang-orang al- muqarrabin (orang-orang yang akrab dengan Allah), dan keempat berdasarkan pengalaman dan kedalaman tauhid penyaksian orangorang al-șiddīqīn (orang-orang yang benar).

Keduanya sama-sama mengakui keberadaan perasaan dan dorongan religius dalam diri manusia yang oleh al-Ghazali diistilahkan dengan fitrah manusia. Selain itu, mereka sama-sama mengakui bahwa pengalaman bersua dengan Tuhan mampu menimbulkan keadaan-keadaan kejiwaan atau psikologi mengalami ekstase religius, antusiasme moral, ketakjuban ontologis, dan emosi-kosmik. Keduanya juga sama-sama mengakui adanya dimensidimensi kedahsyatan, kekhidmatan, serta kebahagiaan, dan juga adanya buah-buah moralitas yang baik, yang dimunculkan oleh pengalaman bersua dengan Tuhan seperti itu. Hanya saja keduanya memakai paradigma dan pendekatan yang berbeda.

Tampak jelas bahwa konstruksi epistemologis yang dibangun oleh William James berbasis pada model epistemologi burhani dan berusaha mendasarkan kebenaran bersumber pada pengalaman empirik. Sementara konstruksi epistemologis yang dikembangkan al-Ghazali berbasis pada model epistemologi irfani dengan mendasarkan kebenaran pada hati atau gnosis. 
Masing-masing pendekatan memiliki kelebihan dan kekurangan. Basis epistemologis yang dijadikan sandaran William James, meski memiliki akurasi ilmiah yang bisa dipertanggung-jawabkan secara moral lebih baik, tetapi ia memiliki kelemahan di tingkat sumber yang dijadikan untuk menghasilkan pengetahuan yang benar. Sebaliknya, basis epistemologis yang dikembangkan oleh al-Ghazali meski memiliki tingkat kedalaman serta universalitas yang jauh lebih baik, tetapi hal itu masih terlalu amat sulit untuk memenuhi kriteria tanggung jawab moral yang menuntut aspek rasionalitas. Oleh karena itu, kedua pendekatan tersebut perlu dikompromikan agar persoalan pengalaman bersua dengan Tuhan bisa diselesaikan secara komprehensif, mendalam, dan objektif.[w] 


\section{BIBLIOGRAFI}

Ali, Yunasril, Manusia Citra Ilahi, Jakarta: Paramadina, 1997.

Ansari, Muhammad Abd. Haq, Merajut Tradisi Syariah dengan Sufisme, terj. Achmad Nashir Budiman, Jakarta: Grafindo Persada, 1997.

Arberry, A.J., Sufism: An Account of the Mystics of Islam (Pasang Surut Aliran Tasawuf), terj. Bambang Herawan, Bandung: Mizan, 1989.

Azhari, Noer, Kautsar, Ibn al-'Arabi Wahdat al-Wujud dalam Perdebatan, Jakarta: Paramadina, 1995.

Atkinson, et.all,, Pengantar Psikologi jilid 1-2, terj. Dra. Nurdjannah Taufiq, Jakarta: Erlangga, 1993.

Bakar, Osman, Hierarkhi Ilmu Membangun Rangka-Pikir Islamisasi Ilmu, terj. Purwanto, Bandung: Mizan, 1997.

Chittick, William C., The Sufi Path of Knowledge, terj. Ahmad Nidjam, M.Sadat Ismail. Dan Ruslani, Yogyakarta: Qalam, 2001.

Devidoff, Linda L., Psikologi Suatu Pengantar, Jakarta: Erlangga, 1988.

al-Faruqi, Isma'il Raji, Tauhid, terj. Rahmani Astuti, Bandung: Pustaka, 1982.

Fathurahman, Oman, Menyoal Wahdatul Wujud Kasus Abdurrauf Singkel di Aceh Abad 17, Bandung: Mizan, 1999.

Gazur-i-Ilahi, Shayk Ibrahim, Mengungkap Misteri Sufi Besar Mansur al-Hallaj "Ana I-haqq," terj. Hr. Bandaharo dan Joebaar Ajoeb, Jakarta: Raja Grafindo Persada, 2000.

Ghazali, Miskāt al-Anwār (Miskat Cahaya-cahaya), terj. Muhammad Bagir, Bandung: Mizan, 1992. Ihyō' 'Ulümal-Dīn, Indonesia: Dar Ihya al-Kutub al-'Arabiyah, tth. al-Munqid min '-Dalāl, Beirut: Dar al-Fikr, 1996. al-Tïbr al-Masbūq fi Nașāih al-Muluk, Riyad: Dar al-'Azariyah, 1994. Majmū' Rasāili, Beirut: Dar al-Fikr, 1996. 
Kimiya' al-Sa'ādah, Beirut: al-Maktabah al-Sya'biyah, t.th. al-Qawā'id al-'Ashrah, Beirut: al-Maktabah al-Sya'biyah, t.th.

Hallaj, al-Husain ibn Manshur, al-Thawwasin, Paris: t.p., 1913.

Hidayat, Komaruddin dan Muhammad Wahyuni Nafis, Agama Masa Depan Perspektif Filsafat Perenial, Jakarta: Paramadina, 1995.

Hidayat, Komaruddin, Memahami Bahasa Agama Sebuah Kajian Hermeneutik, Jakarta: Paramadina, 1996.

Hujwiri, 'Ali 'Utsman, Kasyf al-Mahjub, terj. Suwardjo Muthary dan Abdul Hadi W.M., Bandung: Mizan, 1993.

Iqbal, Muhammad, The Reconstruction of Religious in Islam (Pembangunan Kembali Alam Pikiran Islam), terj. Osman Raliby, Jakarta: Bulan Bintang, 1883.

Izutsu, Toshihiko, Relasi Tuhan dan Manusia, terj. Agus Fahri Husein, Supriyanto Abdullah, dan Amirudin, Yogyakarta: Tiara Wacana, 1997.

James, William, The Varieties of Religious Experience, terj. Gunawan Admiranto, Bandung: Mizan, 2004.

The Will to Believe and Human Immortality, New York and Chicago: Bob Corbett, 1987.

Pragmatism: and Four Essays from The Meaning of Truth, New York: Meridian Books, 1959.

Kalabadzi, ibn Abi Ishaq Muhammad ibn Ibrahim, al-Ta'āruf li Madhhab Ahl alTașawwuf (Ajaran Kaum Sufi), terj. Rahmani Astuti, Bandung: Mizan, 1995.

Khaja Khan, Khan Sahib, Tasawuf Apa dan Bagaimana, terj. Achmad Nasir Budiman, Jakarta: RajaGrafindo Persada, 1995.

King, Richard, Orientalism and Religion Postcolonial Theory, India and 'the Mystic East' (Agama, Orientalisme, dan Poskolonialisme), terj. Agung Prihantoro, Yogyakarta: Qalam, 2001.

Madjid, Nurcholish, et.all, Kontektualisasi Doktrin Islam dalam Sejarah, Jakarta: Paramadina, 1995.

Massignon, Louis, Al-Hallaj Sang Sufi Syahid, terj. Dewi Candraningrum, Yogyakarta: Fajar Pustaka Baru, 2001.

Masyhur, Kahar, Meninjau Berbagai Ajaran, Jakarta: Kalam Mulia, 1986. 
Mubarak, Zaki, at-Tasawwuful Islami fi Adab wa Akhlaq, Jil. II, Mesir: t.p., 1938.

Muhammad, Hasyim, Dialog antara Tasawuf dan Psikologi, Yogyakarta: Pustaka Pelajar, 2002.

Murata, Sachiko, The Tao of Islam, terj. Rahmani Astuti dan M.S. Nasrullah, cet. ke2, Bandung: Mizan, 1997.

Nasr, Seyyed Hossein, Intelektual Islam Teologi Filsafat dan Gnosis, terj. Suharsono dan Jamaluddin MZ, Yogyakarta: CIIS, 1995.

, Knowledge and the Secred (Pengetahuan dan Kesucian), terj. Suharsono, Yoryakarta: Pustaka Pelajar, 1997.

Islamic Art and Spirituality (Spiritualitas dan Seni Islami), terj. Drs. Sutejo, Bandung: Mizan, 1993.

Nata, Abuddin, Metodologi Studi Islam, Jakarta: Raja Grafindo Persada, 2001.

Nawawi, Hadari, Hakekat Manusia Menurut Islam, Surabaya: al-Ikhlas, 1993.

Pals, Daniel L., Seven Theories of Religion, terj. Ali Noer Zaman, Yogyakarta: Qalam, 2001.

Sadra, Mulla, Kearifan Puncak, terj. Dr.Ir. Dimitri Mahayana dan Ir. Dedi Djunardi, Yogyakarta: Pustaka Pelajar, 2001

Sagiran, Mukjizat Gerakan Shalat, Jakarta Selatan: Qultummedia, 2007

Schimmel, Annemarie, Dimensi Mistik Dalam Islam, Yogyakarta: Pustaka Firdaus, 2000.

Schoun, Frithjof, Sufism: Veil \& Quintenssence (Tasawuf Prosesi Ritual Menyingkap Tabir Mencari Yang Inti), terj. Tri Wahono Budhi Santoso, Jakarta: RajaGrafindo Persada, 2000.

Soedjarwo, Dja'far, al-Janibul Illahi, Aspek Ketuhanan Sebagian dari Rasional Islam, Surabaya: al-Ikhlas, 1993.

Stevenson, Leslie dan David L. Haberman, Ten Theories of Human Nature (Sepuluh Teori Hakekat Manusia), terj. Yudi Santoso dan Saut Pasaribu, Yogyakarta: Yayasan Bentang Budaya, 2001

Taftazani, Abu al-Wafa' al-Ghanimi, Sufi dari Zaman ke Zaman, terj. Ahmad Rofi' Utsmani, Bandung: Pustaka,1985.

Tholuck, Priedrich August Deofidus, Sufisme sive Theosophia Persarum Pantheistica, Berlin: t.p.,1921.

Yazdi, Mehdi Ha'iri, Ilmu Huḍuri, terj. Ahsin Mohammad, Bandung: Mizan, 1992.

Walisongo, Volume 20, Nomor 2, November 2012 
Walgito, Bimo, Pengantar Psikologi Umum, Yogyakarta: Andi, 2002.

Wilcox, Lynn, Sufism and Psychology (Psychosufi), terj. Soffa Ihsan, Jakarta: Pustaka Cendekia Muda, 2007.

Wirawan, Sarlito, Pengantar Umum Psikologi, Jakarta: Bulan Bintang, 1982. 